\title{
Back on Track 2: The Principles of Corrective Justice for Performance Enhancing Malpractice in Sports
}

\section{Citation}

Andrea Carska-Sheppard, Paul Weiler \& Jim Medford, Back on Track 2: The Principles of Corrective Justice for Performance Enhancing Malpractice in Sports, 2 Pace. Intell. Prop. Sports \& Ent. L.F. 137 (2012).

\section{Published Version}

http://digitalcommons.pace.edu/pipself/vol2/iss1/6/

\section{Permanent link}

http://nrs.harvard.edu/urn-3:HUL.InstRepos:16200178

\section{Terms of Use}

This article was downloaded from Harvard University's DASH repository, and is made available under the terms and conditions applicable to Other Posted Material, as set forth at http:// nrs.harvard.edu/urn-3:HUL.InstRepos:dash.current.terms-of-use\#LAA

\section{Share Your Story}

The Harvard community has made this article openly available.

Please share how this access benefits you. Submit a story.

\section{Accessibility}




\title{
Pace I.P., Sports \& Entertainment Law Forum
}

\section{Volume 2}

Issue 1 Spring 2012

Article 6

April 2012

\section{Back on Track 2: The Principles of Corrective Justice for Performance Enhancing Malpractice in Sports}

\author{
Andrea Carska-Sheppard \\ andrea.carska-sheppard@smithmoorelaw.com \\ Paul Weiler \\ pweiler@law.harvard.edu \\ Jim Medford \\ jim.medford@smithmoorelaw.com
}

Follow this and additional works at: http://digitalcommons.pace.edu/pipself

Part of the Entertainment and Sports Law Commons

\section{Recommended Citation}

Andrea Carska-Sheppard, Paul Weiler \& Jim Medford, Back on Track 2: The Principles of Corrective Justice for Performance Enhancing Malpractice in Sports, 2 Pace. Intell. Prop. Sports \& Ent. L.F. 137 (2012).

Available at: http://digitalcommons.pace.edu/pipself/vol2/iss1/6 


\title{
Back on Track 2: The Principles of Corrective Justice for Performance Enhancing Malpractice in Sports
}

\begin{abstract}
The first version of this article appeared on the Social Science Research Network more than five years ago. At the time, Andrea Carska-Sheppard, Paul Weiler, and Jim Medford suggested an interdisciplinary debate to bring about solutions urgently needed in the area of performance enhancing malpractice in sports. This was before the Congressional investigations on steroid use, which brought public scrutiny to professional sports. While our society deals (with varying success) with other types of offenses by providing perpetrators with means of support and rehabilitation, we noted there is very little systematic support available to athletes who are suspended for performance enhancing malpractice. The article offered a debate on the legal model that would provide corrective justice and rehabilitation for these types of wrongdoing. In order to create a legal model the authors turned to Professor Weiler's proposed medical malpractice theory and applied it to performance enhancing malpractice. The World Antidoping Agency (WADA) has now adopted its revised Anti-Doping Code and the time has come to revisit our article and the proposed model. What the authors found is that, despite of the passage of time, their proposal is still timely and calls for the attention of all stakeholders. Though the new Anti-Doping Code sheds light on various aspects of doping prosecution and education, it is silent as to the rehabilitation and assistance provision to athletes implicated in doping. The concept of offering a systematic assistance model to the wrongdoers relates to the morality of current and future generations, which cannot be ignored. Instead it is time for the stakeholders to review and examine the model proposed in this article, which would assist athletes and enhance corrective principals in doping malpractice management.
\end{abstract}

\section{Cover Page Footnote}

Andrea Carska-Sheppard is an international trade and business lawyer with Smith Moore Leatherwood LLP in Raleigh, NC. She is licensed in NY State, Canada (Ontario), as a European Registered Lawyer, and she is on the Rolls of Solicitors of England \& Wales. Prior to legal studies, she was a sport journalist. She was a sport journalist. Ms. Carska-Sheppard was a research assistant for Professor Weiler at Harvard Law School. She serves on a variety of international committees, including the International Olympic Commission (Women in Sports) in Lausanne, Switzerland, and the Executive Committee of the International Law Section of the New York State Bar Association. In North Carolina, she serves as Sport Liaison on Dispute Resolution Section of the North Carolina Bar Association and was recently elected to the Council of North Carolina Bar Association's International Section. Her interests include sports and, in particular, acting as a consultant for sports-related entities, companies and associations seeking international expansion.

Jim Medford concentrates primarily on intellectual property litigation, white collar criminal defense and international business agreements with an emphasis on intellectual property at the law firm Smith Moore Leatherwood LLP in Raleigh, NC. Mr. Medford heads the international team at his firm and provides intellectual property counseling to a number of large corporations, domestic and foreign, including licensing, joint research and development, and joint venture work in the NAFTA region, Western Europe (with emphasis on Germany, Switzerland, and Denmark) as well as China and India. He received his J.D. from Harvard Law School, studied at J ohannes Gutenberg Universität in Mainz, Germany and his B.A. from the University of North Carolina at Chapel Hill.

This article is available in Pace I.P., Sports \& Entertainment Law Forum: http://digitalcommons.pace.edu/pipself/vol2/iss1/6 
Paul Weiler is a Henry J. Frendly Professor of Law, Emeritus, at Harvard Law School. He is widely published in labor law, sports law and tort. Professor Weiler completed a bachelor and master of Arts at the University of Toronto, before completing an LL.B. at Osgoode Hall Law School and an LL.M. at Harvard Law School. While a professor of law at Osgoode Hall Law School, he was called upon by the British Columbia government to assist in drafting legislation that brought their Labour Relations Board into existence. He then served as the chairman of the British Columbia Labour Relations Board. Professor Weiler became the MacKenzie King Visiting Professor of Canadian Studies, Harvard University before becoming the Henry J. Friendly Professor of Law. 


\title{
Back on Track 2: The Principles of Corrective Justice for Performance Enhancing Malpractice in Sports
}

\author{
Andrea Carska-Sheppard, Paul Weiler, Jim Medford ${ }^{1}$
}

\section{Introduction}

The first version of this article appeared on the Social Science Research Network more than five years ago. ${ }^{2}$ At the time, we suggested an interdisciplinary debate to bring about solutions urgently needed in the area of performance enhancing malpractice in sports. This was before the Congressional investigations on steroid use $^{3}$ which brought public scrutiny to professional sports.

When we analyzed the issue of performance enhancing malpractice, we noted new angles, which required analysis of, and attention to, the legal sport community and society in general. The time had come to focus not only on the prosecution of athletes implicated in doping offenses but to analyze their needs and provide a corrective model.

While our society deals (with varying success) with other types of offenses by providing perpetrators with means of support and rehabilitation, we noted there is very little systematic support available to athletes who are suspended for performance enhancing malpractice. The article offered a debate on the legal model that would provide corrective justice and rehabilitation for these types of wrongdoing. In order to create a legal model we have turned to Professor Weiler's proposed medical malpractice theory and applied it to performance enhancing malpractice.

\footnotetext{
${ }^{1}$ The contacts for the authors are: andrea.carska-sheppard@smithmoorelaw.com; pweiler@law.harvard.edu; jim.medford@smithmoorelaw.com. The views expressed reflect the views of the authors alone.

${ }^{2}$ Andrea Carska-Sheppard, Paul Weiler and Jim Medford, Back on Track: The Principles of Corrective Justice for Performance Enhancing Malpractice in Sports, SSRN.COM (Oct. 27, 2007), http://papers.ssrn.com/sol3/papers.cfm?abstract_id=1020302.

${ }^{3}$ Jeff Passan, Palmeiro's Shameful End, YAHOO! SPORTS, http://sports.yahoo.com/mlb/news?slug=jppalmeiro080106 (last visited Mar. 17, 2012).
} 
There is no doubt that, just like several years ago, the subject matter of performance enhancing malpractice ignites opposing reactions. As a society, we feel morally reluctant to offer help to those who compete unfairly. On the other hand, we recognize the fact that a doping control system is not error-proof, and that suspended athletes need support and another chance.

The World Antidoping Agency (WADA) has now adopted its revised Anti-Doping Code and the time has come to revisit our article and the proposed model. What we found is that, despite of the passage of time, our proposal is still timely and calls for the attention of all stakeholders. Though the new Anti-Doping Code sheds light on various aspects of doping prosecution and education, it is silent as to the rehabilitation and assistance provision to athletes implicated in doping.

As this insightful comments states " [a]thletes who have been suspended from their sport, even after presenting evidence that the supplements that they were taking were contaminated, suffer tremendously. They are prevented from participating in their sport, often for a lengthy period of time, costing them sums of money in the form of lost salary, lost prize money, and lost endorsements."

The concept of offering a systematic assistance model to the wrongdoers relates to the morality of current and future generations, which cannot be ignored. Instead, as we look forward to London and many other sporting events, it is a good time for the stakeholders to review and examine the model we are proposing in this article, which would assist athletes and enhance corrective principals in doping malpractice management.

\footnotetext{
${ }^{4}$ Howard J. Jacobs, Athlete Lawsuits Against Supplement Companies Following Positive Drug Tests, ALI-ABA Course Materials, Course Number SP016, 1 (2009) [hereinafter Jacobs].
} 


\section{The Strict Liability Standard for Doping}

The arbitration of doping offenses is a game in which athletes never wish to participate. However, if by choice or circumstance they take the stage in this process, they will find themselves on complex legal grounds. The doping offenses dispute resolution system has been criticized for its lack of fairness. ${ }^{5}$

One of the most contentious issues in sports arbitration remains the applicable standard of proof. The root of this uncertainty stems from what standard of proof to use. Ultimately, this is due to an apparent inability to determine the nature of doping offenses. Are these criminal, quasi-criminal or purely civil in nature? Academics question whether this standard of proof should fall closer to proof beyond a reasonable doubt, because doping cases are, at the least, quasi-criminal in nature. Indeed, some may advocate for the preponderance of the evidence standard because doping cases are private in nature. ${ }^{6}$

However, "most sport drug testing applies a strict liability standard of one form or another." What the strict liability standard means is that "that an anti-doping rule violation occurs whenever a prohibited substance (or its metabolites or markers) is found in the bodily specimen of an athlete, whether or not the athlete intentionally or unintentionally used a prohibited substance or was negligent or otherwise at fault." ${ }^{, 8}$ Unlike the negligence standard, the strict liability does not distinguish between the presence or absence of fault on the part of the defendant. As the critics pointed out, the use of strict liability goes against the notion that a "cheater" must have requisite intent and "the system to catch cheaters, which disregards intent, is

\footnotetext{
5 Michael Straubel, Enhancing the Performance of the Doping Court: How the Court of Arbitration for Sport Can Do Its Job Better, 36 Loy. U. Chi. L.J. 1203, 1259-1260 (2005).

${ }^{6}$ Id.

${ }^{7}$ Jacobs at 2.

${ }^{8}$ Anti-Doping Glossary, WADA-AMA (Oct. 2011), http://www.wada-ama.org/en/Resources/Anti-Doping-Glossary/.
} 
destined to sweep up many innocent individuals in its path." ${ }^{\prime 9}$ Despite all criticism, the strict liability was found to be consistent with internationally recognized human rights and general principles ${ }^{10}$ and survived the global consultation process which reviewed the original WADC ("World Anti-Doping Code" and became part of the Revised World Anti-Doping Code which became effective as of January $1,2009 .^{11}$

Scholars of tort law know that strict liability is at least as old as Rylands v. Fletcher. $^{12}$ The proponents of the strict liability theory see it as less messy than the additional showing of fault required in negligence cases. While negligence may appear equitable for showing the athlete's fault, there are practical problems in proving negligence in certain cases. "If plaintiffs experience systematic problems in their efforts to establish fault on the part of defendants perhaps because of the loss or unavailability of evidence -defendants as a class will experience insufficient levels of liability."13 One can see that it was largely for these practical reasons why the strict liability standard is applied in the doping offenses and it is a more efficient solution.

Some strict liability statutes (E.g. for custodians of wild and domesticated animals) are written broadly to impose liability, irrespective of the owner's prior knowledge, and some are less stringent. Likewise, in the doping world, there was an attempt to find a balance by moderating an impact of strict liability standard of Article 2.1.1 by bringing the standards of "no

\footnotetext{
${ }^{9}$ Jessica K. Foschi, Note: A Constant Battle: The evolving challenges in the international fight against doping in sports, 16 Duke J. Comp. \& Int'1 L. 457, 485-486 (2006).

${ }^{10} I d$. at 477.

${ }^{11}$ WADA Consultation Process, WADA-AMA (July 2011) http://www.wadaama.org/en/dynamic.ch2?pageCategory.id=585 (The World Anti-Doping Code was first adopted in 2003 and became effective in 2004. The revisions to the World Anti-Doping Code that were approved by the World AntiDoping Agency Foundation Board on November 17, 2007. The revised World Anti-Doping Code became effective on January 1, 2009).

${ }^{12}$ Rylands v. Fletcher, 3 H. \& C. 774, 159 Eng. Rep 737 (Ex. 1868).

13 James A. Henderson, Richard N. PEARson, \& John A. Soliciano, The Torts Process 429 (Aspen Publishers, $6^{\text {th }}$ ed.) (2003).
} 
fault", "no significant fault" or "negligence" on an athlete's part at the sentencing stage. The

Commentary of the WADC to Article 2.1.1 states:

The strict liability rule for the finding of a Prohibited Substance in an Athlete's Sample, with a possibility that sanctions may be modified based on specified criteria, provides a reasonable balance between effective anti-doping enforcement for the benefit of all "clean" Athletes and fairness in the exceptional circumstance where a Prohibited Substance entered an Athlete's system through No Fault or Negligence or No Significant Fault or Negligence on the Athlete's part. It is important to emphasize that while the determination of whether the anti-doping rule violation has occurred is based on strict liability, the imposition of a fixed period of Ineligibility is not automatic. The strict liability principle set forth in the Code has been consistently upheld in the decisions of CAS. ${ }^{14}$

However, as the sentencing Article 10.5 WADC, which deals with the elimination or deduction of period of ineligibility, states it is only in "truly exceptional circumstances" and "not in the vast majority of the cases" when this Article is operative. As such, its impact is constrained to very rare cases. For example, a total exoneration of the athlete would occur when the athlete can show "that, despite all due care, he or she was sabotaged by a competitor.",15

The defenses under Article 10.5 WADC will be raised whenever the circumstances of the cases so dictate. Whether the reduction in the ineligibility period will be applied on exceptional bases and very rare cases will depend, amongst others, on the quality of the testing procedures. Each year, an increasing number of athletes are tested by the WADA or by other sports bodies ${ }^{16}$, samples are contaminated, or the failure to follow proper testing procedures ${ }^{17}$ occurs. Despite the

\footnotetext{
${ }^{14}$ World Anti Doping Code, Art. 2.1.1 Commentary (2009), available at http://www.wadaama.org/Documents/World_Anti-Doping_Program/WADP-The-Code/WADA_Anti-Doping_CODE_2009_EN.pdf at 19 [hereinafter World Anti Doping Code].

15 World Anti Doping Code, Art. 10.5.1 \& 10.5.2 at 56-57.

${ }^{16} 2010$ ANTI-DOPING ORGANIZATION ACTIVITY SUMMARY REPORTED BY CODE SIGNATORY ANTI-DOPING ORGANIZATIONS (2010), available at http://www.wadaama.org/Documents/Resources/Statistics/ADO_Statistics/WADA_2010_ADO_Statistics_Report.pdf

${ }^{17}$ The CAS panel accepted that the supplemental contamination was likely the cause of the positive urine test. See Knauss v. FIS, CAS, A/847 (Aust.- Switz.) (2005) (It took a professor of law and four third-year law students, all members of the Sports Law Clinic to succeed in representing a professional athlete whose doping test results were shown not be accurate and that scientific procedures were not followed by a testing lab. "Those factors led to a reduction of the otherwise applicable two-year suspension to 18 months.").
} 
best efforts to keep up with research on chemicals, steroids and highly speculative gene doping ${ }^{18}$, the performance enhancing control system for false negatives is not fully reliable. ${ }^{19}$

\section{Consequences of Doping Offenses}

The WADC deals in great detail examining determination of culpability. It addresses issues of the sanctions for the individual and other stakeholders, the need for education to establish an environment that is strongly conducive to doping-free sport, but there is no guidance provided as to what, if any, assistance the individuals implicated in the doping offenses get. In terms of the consequences of doping offenses, the WADC sets them out in regards to individuals ${ }^{20}$, the teams (e.g. target testing) ${ }^{21}$ and sanctions against sporting bodies. ${ }^{22}$ It also deals with the sanctions applicable to athlete support personnel to competent authorities. It provides for the mechanism to determine the period of ineligibility and the athlete's status during period of ineligibility.

An ineligible athlete cannot participate in a training camp, exhibition or practice organized by his or her National Federation or a club, which is a member of that Federation. ${ }^{23}$ It is also made explicit by the rules that "some or all sport-related financial support or other sportrelated benefits received by such Person athlete will be withheld by Signatories, Signatories' member organizations and governments., 24

\footnotetext{
${ }^{18}$ Paul D. Trumble, “Knickel” and Dime Issues: An Unexplored Loophole In New York's Genetic Discrimination Statute And The Viability of Genetic Testing In the Sports Employment Context, 70 Alb. L. Rev. 771 (2007).

${ }^{19}$ Ben Sellenger, Genetic Testing: The Future of Athlete Selection?, 2 Va. Sports \& Ent. L.J. 207, 213 (2003) (warning of the "arbitrary application" of genetic testing in sports).

${ }^{20}$ World Anti Doping Code, Art. 11 at 77.

${ }^{21}$ World Anti Doping Code. Art. 12 at 78. .

${ }^{22}$ World Anti Doping Code, Art. 10.10.1 at 74.

${ }^{23}$ World Anti Doping Code, Art. 10.10.2 at 75-76.

${ }^{24}$ World Anti Doping Code, Commentary Art. 10.10.3 at 75.
} 
The athletes who are suspended may lose the support network that was created for them. A suspension rendered the athlete ineligible to have access to the training facilities of the USOC Training Centers or other programs and activities of the USOC, including grants and awards of employment. ${ }^{25}$ One of the clearer statements what happens to the suspended athletes after the adjudication, admission or acceptance of the doping offense is provided by the United States Olympic Committee ("USOC) Anti-Doping Polices in Annex C. ${ }^{26}$ It is made explicit that the athlete loses the direct athlete support and, after the conclusion of the suspension, he/she will have to re-qualify for athlete support programs (e.g., attain appropriate rank, etc.). The suspended athletes cannot be considered for a tuition grant during any period of suspension but if an athlete loses only the result, the tuition grant is maintained. First time violators of Section 10.3 of the World Anti-Doping Code keep their access to the Olympic Training Center and Olympic Training Sites as well as the Olympic training center residence.

First time violators keep their other USOC benefits, such as career consulting, access to the Athlete Service Center, media services, personal development programs, resource library access, sport science and coaching. What is less clear is to what extent the Athlete marketing services (including access to sponsor programs) are provided because, as stated on the website, "[p]articipation in the OJOP program and sponsor programs will also be dependent on employer or sponsor views" ${ }^{27}$ which may result in a rather arbitrary standard. Elite Athletes, who are first time violators of Section 10.3 of the World Anti-Doping Code, do not lose the health insurance

\footnotetext{
${ }^{25}$ United States Anti-Doping Agency v. Mark Hainline, A.A.A. Case No. 301900078905 (2005) (Gans, Brunet, Witherspoon, Arb.).

${ }^{26}$ Annex C To USOC National Anti-Doping Policies, TEAm USA, http://www.teamusa.org/resources/teamusanet/athlete-services/usoc-suspension-of-benefits-policy (last visited Feb. $8,2012)$.

${ }^{27} I d$.
} 
for the period of suspension. ${ }^{28}$ The Elite Athlete program offers eligible athletes a level of base support by offering a program of health and major medical insurance for designated Elite Athletes in order to minimize the out-of-pocket expenses incurred by insured athletes for costs of medical care. $^{29}$

As is specified by the USOC under the World Anti-Doping Code, NGBs ("National Governing Bodies"), as members of a Code signatory (the USOC), must engage in the same or similar suspensions of benefits and access as the USOC. NGBs are to adopt policies similar to those adopted by the USOC within this policy, subject to USOC approval. There is very little systematic support provided to the athletes.

Beyond the institutional impact, there are personal consequences to the athletes, who suffer emotionally and economically as a result of allegations/being implicated in the doping malpractice. In some, but not all cases, the arbitration costs are born by the athletes' Olympic committee or federation. ${ }^{30}$ Those who have to finance their arbitration and lose leave the process morally condemned and financially depleted, facing the prospect of temporary or permanent unemployment, usually with very modest transferable skills. To support their living, only a small group can rely on their personal savings and/or endorsement insurance. The rest are left, to large extent, on their own to cope with moral stigma, little or no transferable skills, and no clear possibility for making a comeback.

\footnotetext{
${ }^{28} \mathrm{Id}$.
}

${ }^{29}$ Elite Athlete Health Insurance Information (EAHI), TEAM USA, http://www.teamusa.org/resources/teamusanet/athlete-services/elite-athlete-health-insurance-information-eahi (last visited Feb. 8, 2012).

${ }^{30}$ Id. 


\section{Turning for Assistance}

Doping raises concerns not only in sports but in a social context as well. ${ }^{31}$ Numerous international instruments (i.e., the World Anti-Doping Code, the Athlete Outreach Model, ${ }^{32}$ the Lausanne Declaration on Doping in Sport, ${ }^{33}$ and the International Convention Against Doping in Sport $^{34}$ ) were developed to prevent and detect the problem of doping, but now we need to move a step further and recognize that the current doping control system needs not only to punish and deter but must also play a role in the rehabilitation of the athletes. Unlike other wrongdoers, suspended athletes have no predictable support network and no counselors "on hand."

One of the forms of risk management in law and economics is insurance. It provides transfer of risk from one entity to another in exchange for the payment. This raises question how the insurance industry deals with the performance enhancing malpractice in sports. As we will show, the insurance companies have "strong policy reasons for limiting coverage in case of some intentional harm. $" 35$ As such, how the individual insurers deal with the insurance contracts and how they can provide source of assistance for the athletes who have been involved in doping is a grey area.

To start with, there are only a small number of companies that specialize in insurance products for athletes, such as K\&K Insurance providers and Lloyds of London. Given the high risks associated with sports and the susceptibility of the athletes to various types of injuries, this

\footnotetext{
${ }^{31}$ George W. Bush, President of the United States of America, State of the Union Address at a Joint Session of Congress (Jan. 20, 2004), transcript available at http://www.washingtonpost.com/wp-

srv/politics/transcripts/bushtext_012004.html (last visited Mar. 17, 2012). In the 2004 State of the Union Address, it was mentioned that the use of performance-enhancing drugs, even in a minority of elite athletes, sets a dangerous example for the millions of young Americans.

${ }^{32}$ Doping Lusanne Declaration (Feb. 4 1999), available at http://www.la84foundation.org/OlympicInformationCenter/OlympicReview/1999/OREXXVI25/OREXXVI25g.pdf

33 Adopted by the World Conference on Doping in Sport 4 February 1999, Lausanne, Switzerland.

${ }^{34}$ Council of Europe Anti-Doping Convention No. 135, Nov. 16, 1989., S. TREATY Doc. No. 110-14, E.T.S. 135; see also John R. Crook, United States Supports New UNESCO Instruments on Doping in Sports and on Bioethics; Votes Against New Convention on Cultural Diversity, 100 AM. J. INT'L L. 229 (2006).

35 TOM BAKER, InsuranCE, LAW AND POLICY 478 (Aspen Publishers, $1^{\text {st }}$ ed. 2003).
} 
low concentration of insurance product providers is understandable. The insurance coverage for athletes usually carries a high price tag. In order to get coverage, the athletes must undergo intensive medical evaluations by both their teams and the insurance companies to determine the likelihood of having a predisposition to a particular illness, but even the athletes who are healthy and very successful have to pay enormous amounts to insure their contracts. ${ }^{36}$ Other than contract insurance, there are number of insurance products specifically designed for athletes and the sports industry; i.e.., Accidental Death and Dismemberment, Temporary Total Disability, Permanent Total Disability, Kidnap and Ransom, Image Protection, Critical Asset Protection, Contractual Bonus, Insurance programs for elite athletes, future earnings against injury, Personal Accident and Team Stop Loss. Most of these insurance products are not specific about the coverage for athletes who are charged with being under the influence of drugs or narcotics that are not lawfully available.

Further, it is also unclear which substances or methods listed on the WADA's Prohibited List carry with themselves criminal penalties. ${ }^{37}$ This is country-specific but creates difficulty for the insurers. On the one hand there is an athlete who was charged by performance enhancing malpractice by an international body of law, on the other hand there is an insurance contract governed by chosen law and usually silent on exclusions for the performance enhancing malpractice. The current process seems to be thus based more on the case-by-case determination. $^{38}$

\footnotetext{
${ }^{36}$ For example, Daniel Alfredsson would have to pay more than $\$ 1$ million to insure his five-year, $\$ 32.5$-million US deal with the Senators to play back home in Sweden.

${ }^{37}$ World Anti-Doping Agency, The World Anti-Doping Code: The 2006 Prohibited List (Sept. 19, 2005), available at http://www.internationalgolffederation.org/MemberOnly/pdf/2\%20-\%202006\%20Prohibited\%20List.pdf (WADA's Prohibited List includes the substances and methods that are prohibited: 1) at all times; 2) in competition; and 3) in particular sporting events. It also references so-called specialized substances).

${ }^{38}$ The rumors of doping by Lance Armstrong were enough for SCA, a Texas Insurance company, to refuse to pay the six-time Tour de France winner the $\$ 5 \mathrm{M}$ bonus that became due to him when he broke the record for victories. At the initial stage, all the evidence the SCA had against him was circumstantial speculation by the authors of an
} 
This lack of interest and systematic assistance should raise serious concerns. These individuals are treated differently than other vulnerable members of society who can rely on a support network provided by their community or their professional organizations.

\section{Professor Weiler's Radically Moderate Correlative Model and Doping Malpractice}

In order to balance this imbalanced situation for these athletes in comparison with other wrongdoers, we need to inquire as to what can be done to bring these athletes back on track. To better extrapolate this situation, we need to analyze it from the corrective justice point of view.

Citing Aristotle, Professor Weinrib contrasts corrective justice with distributive justice. ${ }^{39}$ While distributive justice is concerned with "proportional equality, in which all participants in the distribution receive their shares according to their respective merits under the criterion in question," the corrective justice "features the maintenance and restoration of the notional equality with which the parties enter the transaction." ${ }^{40}$ It links the doer and sufferer of an injustice in terms of their correlative positions. ${ }^{41}$

When devising a reform model for medical malpractice, Professor Weiler adopted what he calls a radically moderate approach for examining the correlative positions of all the parties involved. In our first Back on Track ${ }^{42}$ article, we introduced his reform proposal and examined

unauthorized biography in France. Ultimately, the SCA had to retract its premature exclusion and paid the bonus. However, this example shows how allegations of performance enhancement can prompt insurers to take adverse actions against athletes who have never been sanctioned. William Fotheringham, Insurers withhold $\$ 5 \mathrm{~m}$ Tour bonus for Armstrong, THE GUARDIAN (Sept. 23, 2004), http://sport.guardian.co.uk/tourdefrance2004/story/0,14667,1310624,00.html.

${ }^{39}$ Ernest J. Weinrib, Corrective Justice in a Nutshell, 52 U. Toronto L.J. 349 (2002).

${ }^{40} I d$.

${ }^{41} I d$. at 351.

${ }^{42}$ Andrea Carska-Sheppard, Paul Weiler and Jim Medford, Back on Track: The Principles of Corrective Justice for Performance Enhancing Malpractice in Sports, SSRN (Oct. 27, 2007), http://papers.ssrn.com/sol3/papers.cfm?abstract_id=1020302. 
whether any elements of his model can be transposed into solving correlative issues in performance enhancing malpractice.

The analysis of Professor Weiler's model included assessment of the "vulnerable stakeholders in the medical malpractice system," as well as the proposition that traditional personal liability of individual physicians needs to be replaced by a new full-blown enterprise liability of health care organizations. It was followed by the proposal that it was necessary for the responsible organization in the medical malpractice context to create an internal peer review committee as one of its quality assurance programs. Lastly, the model stated that to bring malpractice reform even further would require a radical move from fault to no-fault liability, which would treat injured patients in the same fashion as injured nurses.

Summing up, three pillars of Professor Weiler's proposed medical malpractice reform are enterprise liability of the health care organization for the wrongdoing of doctors, a peer review system implemented by the health care organization, and no-fault liability for the injured patients. These pillars redefine the respective position of the parties and would restore the notional equality with which the parties enter the transaction when they seek treatment. We had then examined whether any of these principles can be transposed to performance enhancing malpractice and, as we will show, it is feasible to apply two out of three elements in this new context.

Unlike in medical malpractice where the injuries are often the result of the high-risk medical profession in which the doctors commit the wrong unintentionally; the athletes usually, but not always, resort to taking performance-enhancing substances by their own choice. Unfortunately, the current testing is not risk free and innocent victims can become implicated in the doping scandals. Obviously, the testing has to keep up with and preferably keep ahead of 
science but, given these risks, it is feasible that other bodies, such as the sports organizations, should step in to bear the risk of the process, which is not free of wrongful convictions. Though admittedly the wrongful convictions are rare, the effects on wrongly convicted individuals are profound. These are reasons why enterprise liability, which was also introduced in the medical malpractice model, should apply in the present context.

The theory of enterprise liability, according to Gregory C. Keating, "asserts "that (1) accident costs should be internalized by the activity responsible for them; and (2) accident costs should be dispersed and distributed among the participants in that activity. This idea can be incarnated by strict liability in tort, but it can also be incarnated in other ways. Indeed, enterprise liability first appears in Worker's Compensation schemes enacted early in the twentieth century. Enterprise liability in tort generally involves imposing strict liability on injurers, but its aim can also be affected by mandatory loss insurance. Compulsory loss insurance spreads an activity's accident cost among all the potential victims of an activity, each of whom pays a premium to spread his or her share of the risk." ${ }^{43}$

However, this enterprise liability model would differ from the medical malpractice in that it would continue applying the current strict liability regime rather than the no-fault regime. The enterprise liability would require sports organizations to underwrite compulsory loss insurance in order to generate funds aimed for professional rehabilitation of athletes.

\section{Feasibility of the Proposed Model}

Naturally, the issue arises whether this well-intended model is subject to abuse by repeated wrongdoers and it raises concern about the risk of anti-selection. In the insurance world, anti-selection occurs when high-risk individuals purchase more insurance than those with

\footnotetext{
${ }^{43}$ Gregory C. Keating, 74 So. Cal. Law Rev. 216-217 (2000)
} 
normal-risk exposure. This could lead to an overall premium increase in order for insurers to protect themselves. ${ }^{44}$

We believe that though there is such a risk, the loss of endorsements, faith and the moral stigma associated with doping are factors that will give disincentive for abuse of this model. The policy principle, which we seek to achieve, is to protect innocent victims from wrongful convictions and "put back on track" a broad population of athletes. Clearly, in order to achieve the deterrence aspect, the endorsement insurance should not be available to repeated wrongdoers.

In addition, to give a disincentive for athletes to rely on the insurance and engage in performance enhancing malpractice, each sport federation could set up an internal peer review committee. The funds would be payable to the committee in trust for the athlete who is in the process of rehabilitation. This system will provide impetus for the sports organization to be more vigilant and internally manage/suppress any suspicion of the doping activity at its root.

To be eligible for this income, the athlete will need to cooperate with the peer review committee, truly disclose the circumstances of the doping offense and spend a number of hours in community service. The peer review committee will be constituted by two members appointed by the federation and one member designated by the athlete and will also provide emotional support and monitor the come-back of the athlete.

In addition, individual sport federations/organizations may also choose to negotiate a short-term disability insurance that would pay for living expenses during the suspension, but this would have to be explored separately. It also seems to be the case, that if we want the athletes and sports organizations to be covered by certain insurance policies, we need to steer away from

\footnotetext{
${ }^{44}$ Christopher M. Keefer, Bridging the Gap Between Life Insurer and Consumer in the Genetic Testing Era: The RF Proposal, 74 Ind. L.J. 1375, 1384-1385 (1999).
} 
classifying the performance enhancing malpractice as criminal or quasi-criminal, and treat them more like "sui generis" offenses.

In addition, the insurance companies can assume a more active role and have more control over the process. The time may be ripe for insurers to reach beyond their traditional roles in relation to sports. "Over the years, insurance institutions have been a significant force in the development and dissemination of harm-reducing technologies and practices." 45 This involvement of insurance companies in testing and developing new technologies did not happen randomly, but this trend is rooted in the core function of insurance institutions, which is harm prevention. "It is not uncommon for insurance companies to test and rate the crashworthiness of cars or to establish the underwriter's labs to test materials for resistance to fire and other hazards. ${ }^{46}$

As such, the insurers who would underwrite specialized insurance for the sports organizations/federations to cover athletes' expenses during their doping suspensions, may be more motivated to become involved in risk prevention - developing more accurate doping control systems. This would bring added value, not only for the parties involved, but also to society in general because more precise testing would reduce the risk of wrongful suspensions.

However, even if the insurers and sports federations would be willing to consider such a new model, we need to ask ourselves whether such a system would not be contradictory to the deterrence objective of the doping suspensions.

First, this support model will not be available to permanently suspended athletes who are repeat offenders because this type of relief only provides a temporary means of support. In addition, the athletes who will benefit from this assistance will ultimately have to pay their dues

\footnotetext{
${ }^{45}$ TOM BAKER, InSURANCE, LAW AND POLICY, 478 (Aspen Publishers, $1^{\text {st }}$ ed. 2003).

${ }^{46} I d$.
} 
back when they reenter the competition and negotiate their insurance policies. As part of negotiating the insurance policy, they will have to disclose their history of doping, which will result in paying higher insurance premiums.

\section{Conclusion}

As we are gearing up for the 2012 Summer London Olympics and future international sporting events, the organizers of theses events spend great effort and resources to educate the athletes by launching "win clean campaigns" "47 and other measures. The issue of assisting athletes who engage or are accused of engaging in performance enhancing malpractice is also a moral question about whether our society wants to assist individuals who presumably compete unfairly, in order to gain advantage over others and receive undeserving glory. There is an aspect of paternalism in providing a helping hand to these individuals. However, this proposed corrective model is not imposed or mandated. It is up to each sport's organization/federation to consider its applicability to their particular sport, culture and region and adopt it in conjunction with the specialty insurance providers, which would best serve their needs.

Our societies seek to provide a system of support and rehabilitation for all types of morally reprehensible forms of conduct. There is no reason for not providing it for those who engage in performance enhancing malpractice. There are many athletes who regret their bad decisions and wish "to come back on track", compete, inspire others who are outside of the field of sports, and also hope for a second chance.

\footnotetext{
47 'Win Clean' anti-doping campaign launched, LONDON 2012 (Oct. 11, 2011), http://www.london2012.com/news/2011/10/-win-clean-anti-doping-campaign-launched.php; see also Alok Jha, London Olympics Athletes Given Anti-Doping Warning by Scientists, THE GUARDIAN (Sept. 12, 2011), http://www.guardian.co.uk/science/2011/sep/12/london-olympics-2012-anti-doping.
} 